\title{
Lapsuuden loppu ja Inkerinmaa Juhani Konkan muistelmateoksissa
}

\author{
Kasvu, ylirajaisuus ja kahden nykyisyyden muisti
}

\section{Ulla Savolainen}

$\mathrm{T}$ ässä artikkelissa tarkastelen kasvun teemaa sekä ylirajaisuutta Juhani Konkan kahdessa, samoja osia sisältävässä muistelmateoksessa Kahden maailman rajalla (1939) ja Pietarin valot (1958) kulttuurisen muistin näkökulmasta. Juhani Konkka (1904-1970) oli inkerinsuomalainen kirjailija, toimittaja ja venäjänkielisen kirjallisuuden suomentaja, joka vuonna 1919 siirtyi Neuvosto-Venäjän Inkerinmaalta Suomeen. Hänen tuotantoonsa kuuluu muun muassa 1930-luvun taitteessa Urho Torikan nimellä julkaistut Aunuksen sotaretkeä sekä vallankumouksen jälkeisiä aikoja Inkerissä kuvaavat romaanit Me sankarit: Kuvaus Karjalan retkeltä (1929) ja Punainen myrsky: Romaani Inkerinmaalta (1931). 1940-luvulla Konkka julkaisi muun muassa "Kulkuri"-romaanitrilogian (Konkka 1943; 1945; 1946), jonka tapahtumat perustuvat Konkan vaiheisiin Suomessa sekä 1930-luvun Helsingin kirjallisuuselämää kuvaavan romaanin Tuhlattu aarre, eli, Sakari Korkian seikkailut Helsingin kirjailija- ja boheemimaailmassa (1947). Tässä artikkelissa analysoidut muistelmateokset kuvaavat kirjoittajan lapsuuden ja nuoruuden aikaa Inkerissä, lokakuun vallankumouksen jälkeisiä yhteiskunnallisia muutoksia sekä kirjoittajan siirtymistä Suomeen.

Juhani Konkkaa on pidetty yhtenä merkittävimmistä inkeriläisistä kirjailijoista (Nevalainen 1999, 256; ks. myös Sihvo 1991), mutta hänen kirjallista tuotantoaan on tutkittu hyvin vähän (Linna 2014, 15-18). Vaikka inkeriläisyys ja Inkeri sekä niiden suhde Suomeen ja (Neuvosto-) Venäjään ovat keskeisiä aihepiirejä Konkan muistelmateoksissa, ei niitä ole huomioitu tutkimuksessa juurikaan (ks. kuitenkin Sihvo 1991; Nevalainen 1999, 256). Konkkaa, hänen työtään ja kirjallista tuotantoaan sivuava tutkimus onkin keskittynyt lähinnä hänen poliittiseen toimintaansa ${ }^{1}$, hänen opintoihinsa Yhteiskunnallisessa Korkeakoulussa (esim. Linna 2014; ks. myös Nevalainen 1999, 256; Nevalainen 2006, 222, 226-227; Tarmio 1985) tai hänen työhönsä suomentajana (Jänis 2007; Paloposki 2009). Yleisemminkin inkeriläisten kokemuksia käsittelevän kirjallisuuden tutkimus on ollut toistaiseksi hyvin vähäistä (ks. kuitenkin Sihvo mukaan "1930-luvun alussa valtiososialistisessa puolueessa näkyvästi toheltanut Juhani Konkka oli ristiriitainen hahmo", joka suututti heimopiirit ja josta tehtiin talvisodan aikaan ilmiantoja kommunistiksi syytettynä. Valtiososialistisella puolueella viitataan vuonna 1932 perustettuun Suomen Kansallissosialistiseen Liittoon, jonka perustajiin Konkka kuului. Hän myös toimi sen puoluesihteerinä 1933-1934 ja päätoimitti puolueen Kansallissosialisti-lehteä. (Konkan henkilöhistoriasta ja toiminnasta ks. esim. Ekberg 1991; Koskela 1997; Lassila 2002; Jänis 2007; Linna 2014.) 
1991; Vettenniemi 2001; Venäjän Karjalan kirjallisuudesta Kurki 2018)². Artikkelissani osoitan, että Juhani Konkan kaksi muistelmateosta avaavat moniulotteisen näkökulman Inkerinmaan dramaattiseen 1900-lukuun, siihen liittyviin kokemuksiin sekä Inkerin ylirajaiseen asemaan kulttuurisen muistin näkökulmasta.

\section{Kulttuurinen muisti näkökulmana}

Analyysissäni keskityn Juhani Konkan muistelmateosten kahteen keskeiseen teemaan, kasvuun sekä ylirajaisuuteen suhteessa Inkeriin, Suomeen ja (Neuvosto-)Venäjään. Analysoin artikkelissani kasvun tematiikkaa kulttuurisen muistin näkökulmasta suhteuttamalla sitä keskeisiin moderneihin elämänkulun esittämisen kirjallisiin malleihin, modernin omaelämäkerran ja kehitysromaanin lajeihin. Analyysini pohjautuu osaltaan huomioon siitä, että Konkan teokset sisältävät suoria viittauksia näihin lajeihin. Luen nämä viittaukset tulkintaehdotuksina ja -kehotuksina.

Humanistisessa ja sosiaalitieteellisessä tutkimuksessa ylirajaisuuden käsitteellä ${ }^{3}$ on kaksi osittain päällekkäistä käyttötarkoitusta. Ensinnäkin sillä viitataan tarkasteltavaan ilmiöön (kuten kirjallisuuteen tai identiteettiin) esimerkiksi valtioiden, kansakuntien, etnisyyksien tai kielten kategorioiden rajat ylittävänä. Toisaalta sillä viitataan analyyttiseen näkökulmaan, joka tarkastelee kategorioiden rajojen ylityksiä ja vuorovaikutusta pyrkien usein kriittisesti purkamaan essentialistista ymmärrystä kulttuureista ja metodologista nationalismia. (Ks. esim Grönstrand et al. 2016; De Cesari ja Rigney 2014; Bond ja Rapson 2014; Vertovec 2009.) Artikkelissani käytän käsitettä ennen kaikkea sen ensimmäisessä merkityksessä (joka ei sulje pois toista) viittaamalla ylirajaisuudella Konkan muisteluteosten keskeiseen teemaan, kansallisen asemoitumisen pohdintaan.

Artikkelini edustaa monitieteistä kulttuurista muistitutkimusta, etenkin sen kulttuurin- ja taiteen tutkimuksen sekä muistin välittymisen kysymyksiin keskittyvää suuntausta (esim. Rigney 2005; Erll ja Rigney 2009; Erll 2011 b; Kaljundi, Laanes ja Pikkanen 2015; Heimo 2017). Kulttuurinen muisti viittaa alati muuntuvaan representaatioiden ja käytänteiden joukkoon, esimerkiksi kertomuksiin, kuviin tai rituaaleihin, joiden kautta menneisyys siirtyy ja siirretään nykyhetkeen ilmaisemaan ja vakiinnuttamaan yhteisön ja yksilöiden itseymmärrystä (esim. Assmann 1995, 132; Rigney 2016, 66-67; myös Erll 2011a, 6-7). Kulttuurisen muistin olemus on dynaaminen ja välittyvä eli se syntyy, kun kulttuurisia representaatioita tulkitaan uusissa välineissä, muodoissa, ajoissa ja paikoissa. Toisin sanoen muisti ei niinkään tallenna ja toista vaan muuntelee ja tulkitsee. Muistin prosesseissa representaatiot muuttuvat ja synnyttävät uudenlaisia merkityksiä kulloistenkin tarpeiden mukaisesti. Puhutaankin muistin välittymisestä (mediation) ja uudelleen välittymisestä (remediation). (Erll ja Rigney 2009; Erll 2011 b; Erll 2018.) Astrid Erll (2017) on tuonut esiin, että kulttuurissa olemassa olevat kollektiivisesti tunnistetut resurssit ja mallit (esim. Odysseuksen hahmo, ks. Erll 2018) välittävät myös ennalta (premediate) kokemuksia ja muistia eli toisin sanoen ohjaavat tapoja ymmärtää ja tuottaa menneisyyttä nykyhetkessä ja tulevaisuudessa. Ne siis toimivat eräänlaisina kehyksinä, jotka mahdollistavat elämästä kertomisen ja tekevät muistoista kerrottavia kussakin nykyisyydessä mielekkäällä tavalla (Savolainen 2017b; Savolainen 2018).

$2 \quad$ Inkeriläisten kertomuksia tai muistelua on kuitenkin tutkittu haastattelu- ja kirjeaineistojen kautta (esim. Kaivola-Bregenhøj 1999; Survo 2001; Jääskeläinen 2001; Miettinen 2004; Peltonen 2009). Myös inkeriläisten paluumuuttoon liittyviä kokemuksia on tutkittu (esim. Reijonen 2002; Huttunen 2002; Miettinen 2004; Davydova 2009; Salonsaari 2018). 
Kulttuurisen muistin näkökulma merkitsee artikkelissani ensinnäkin sitä, että tarkastelen modernin omaelämäkerran ja kehitysromaanin lajeja kulttuurisen muistin resursseina ja sen ilmentyminä. Ne ovat kehyksiä, jotka välittävät kulttuurisia tapoja ymmärtää ja esittää yksilön kasvua sekä suhdetta kollektiiviseen. Siten ne myös mahdollistavat yksilön menneisyyden jäsentämisen suhteessa yhteiskuntaan ja sen historiaan nykyisyyden näkökulmasta mielekkäällä tavalla. Artikkelissani esitän, että Juhani Konkan muistelmateoksissa modernin omaelämäkerran ja kehitysromaanin lajit toimivat kehyksinä hänen henkilökohtaisen menneisyytensä, yhteiskunnallisen ja sukupolvisen muutoksen sekä Inkerin ylirajaisen aseman pohdinnalle. Tätä kautta nämä kehykset liittyvät myös Konkan yhteiskunnallisten ja poliittisten näkemysten ilmaisuun sekä hänen asemoitumiseensa suhteessa Inkeriin, Suomeen ja Neuvostoliittoon. Tämänkaltaiset neuvottelut yksilön elämästä ylirajaisessa kontekstissa eivät luonnollisesti koske yksinomaan Juhani Konkan kirjallisuutta tai Inkeriä. Katson, että ne kytkeytyvät olennaisesti moderniin tapaan hahmottaa yksilön ja kollektiivin suhdetta kansallisiin viitekehyksiin asemoitumisen sekä niihin kytkeytyvän ambivalenssin kautta.

Toiseksi kulttuurisen muistin näkökulma merkitsee artikkelissani sitä, että tulkitsen teoksia suhteessa niiden ilmestymisajankohtiin. Koska teosten ilmestymisvuosien (1939 ja 1958) välillä on lähestulkoon parikymmentä vuotta aikaa, ne representoivat ja tulkitsevat lokakuun vallankumouksen jälkeisiä tapahtumia verrattain erilaisista nykyisyyksistä käsin. Ilmestymisajankohtien väliin ajoittuu merkittäviä historiallisia tapahtumia mukaan lukien talvi-ja jatkosodat sekä niitä seurannut murros Suomen ja Neuvostoliiton suhteissa. Teosten ilmestymisajankohtien väliin ajoittuu myös kokemuksia, joita Konkka erittelee jälkimmäisessä teoksessaan. Analysoin artikkelissani sitä, miten omakohtaisen menneisyyden merkitykset muovautuvat teoksissa suhteessa erilaisiin nykyhetkiin, sekä sitä, miten erilainen kehystys teoksen sisällä vaikuttaa samoille historiallisille tapahtumille ja kokemuksille annettuihin merkityksiin.

\section{Inkerinmaan ja inkeriläisten ylirajainen historia}

Juhani Konkka syntyi vuonna 1904 Toksovassa Inkerinmaalla (Koskela 1997). Inkeri tai Inkerinmaa on Venäjällä, Pietarin kaupungin ympärillä sijainnut, lännessä Viroon ja pohjoisessa Karjalankannakseen rajautunut historiallinen alue. Inkerinsuomalaisiksi (joskus pelkästään inkeriläisiksi) ${ }^{4}$ kutsutaan 1600 -luvulta lähtien alueelle Suomen alueelta muuttaneiden siirtolaisten jälkeläisiä. Tuolloin Inkerin ja Suomen alue olivat osa Ruotsin valtakuntaa. Luterilaisten ja suomea puhuneiden inkerinsuomalaisten lisäksi monikulttuurisen ja -uskonnollisen Inkerinmaan väestö koostui muun muassa inkeroisista, vatjalaisista, venäläisistä, virolaisista ja saksalaisista. Alueena Inkeri ei ole koskaan muodostanut itsenäistä valtiota. (Matley 1979, 1-10; Kallio 2013, 34-48; Survo 2001; Hakamies 1991; Nevalainen 1990, 13-24.) 1700-luvun alussa Venäjän keisari Pietari Suuri valloitti alueen Ruotsilta ja aloitti Pietarin kaupungin rakennustyöt. Huolimatta Pietarin kaupungin merkittävästä kasvusta 1700- ja 1800-luvulla huomattava osa inkerinsuomalaisista oli edelleen luterilaisia ja puhui äidinkielenään suomea. 1800-luvun jälkimmäiseltä puoliskolta alkaen kansallisromanttiset ajatukset heimoyhteydestä suomensukuisten kansojen välillä olivat muodikkaita niin Suomessa kuin Inkerinmaalla. Kulttuurinen ja kansallinen identifioituminen suomalaiseksi olikin tavallista etenkin inkerinsuomalaisen sivistyneistön ja yläluokan keskuudessa. Vuonna 1919

$4 \quad$ Inkeriläinen-nimitystä käytetään usein inkerinsuomalaisen synonyyminä, niin tutkimassani kirjallisuudessa kuin muissakin yhteyksissä. Itse käytän nimitystä inkeriläinen laajassa merkityksessä viittaamaan Inkerinmaan asukkaisiin heidän kielellisestä, kansallisesta tai uskonnollisesta taustastaan riippumatta. 
inkerinsuomalaisten määrä Inkerinmaalla oli noin 130000 henkilöä. (Matley 1979, 4; Nevalainen 1991, 234-237; 1990, 18-24.)

Venäjän vallankumouksia seuranneet yhteiskunnalliset muutokset vaikuttivat Pietarin (myöhemmin Petrograd ja Leningrad) ympäristössä asuneiden inkeriläisten elämään peruuttamattomasti. Ne myös aktualisoivat kysymyksen Inkerin kansallisesta asemasta uudella tavalla. (Nevalainen 1990, 18-24; Sihvo 1991, 323-342; Flink 2000.) Huolimatta siitä, että osa inkeriläispoliitikoista toivoi Inkerin itsenäistymistä tai sen liittämistä Suomeen, Inkerinmaa jäi Tarton rauhansopimuksessa 1920 osaksi Neuvosto-Venäjää (myöhemmin Neuvostoliittoa). (Matley 1979, 5; Nevalainen 1991, 237-253; 1990, 18-21.) Tähän sekavaan aikaan ennen ja jälkeen Tarton rauhansopimusta ajoittuvat Juhani Konkan muistelmateosten keskeistapahtumat. Molemmat teokset on kuitenkin julkaistu vasta vuosia näiden tapahtumien jälkeen. Näin ollen on mielekästä olettaa, että niitä ei luettu ainoastaan suhteessa niiden kuvaamiin tapahtumiin vaan myös suhteessa ajallisesti myöhempiin tapahtumiin, etenkin 1920-luvun lopulla alkaneeseen neuvostosortoon.

Pakkokollektivisointia sekä mielivaltaisia vangitsemisia, väkivaltaa ja karkotuksia sisältäneet sortotoimet alkoivat Inkerinmaalla laajamittaisesti 1920-luvun lopulla. Ensimmäiset joukkokarkotukset tapahtuivat vuosina 1929-1931 ${ }^{5}$. Toiset ja kolmannet laajamittaiset karkotukset tapahtuivat vuosina 1935-19386. Kaiken kaikkiaan on arvioitu, että maailmansotien välisenä aikana noin 45 000-60 000 inkerinsuomalaista karkotettiin ja vangittiin Neuvostoliitossa. Tuhansia Inkerinmaan asukkaita pakeni myös Suomeen, Viroon ja Saksaan. (Matley 1979, 9-10; Nevalainen 1991, 254-260; myös Peltonen 2009, 61-62.) Toisen maailmansodan aikana osa Inkerinmaasta jäi Natsi-Saksan piiritysvyöhykkeeseen ja noin 60000 inkerinsuomalaista evakuoitiin Suomeen sodassa samalla puolella olleiden Suomen ja Saksan yhteisellä sopimuksella. Vuonna 1944 Suomen ja liittoutuneiden maiden välirauhansopimuksen myötä 55 000 Suomeen evakuoiduista inkerinsuomalaisista palasi Neuvostoliittoon, jossa heidät pakkosijoitettiin monille tahoille (Matley 1979, 10-12; Nevalainen 1990; 1991, 267-288; Flink 2010.) Neuvostoliiton hajoamisen aikana vuonna 1990 Suomi käynnisti inkeriläisten paluumuuton. Sittemmin vuosien 1990-2016 välillä noin 30000 inkeriläistaustaista henkilöä on muuttanut Venäjältä Suomeen (ks. Salonsaari 2018).

\section{Inkeriläisten kokemuksia kirjallisuudessa}

Vangitsemiset, karkotukset sekä ylirajaisuuteen liittyvät kysymykset ovat keskeisiä teemoja inkeriläisten 1900-luvun kokemuksia käsittelevässä kirjallisuudessa7. Ajallisesti tämä kirjallisuus voidaan karkeasti jakaa kolmeen ryhmään (ks. tarkemmin Sihvo 1991). Ensimmäinen ryhmä koostuu maailmansotien välissä kirjoitetuista teoksista ja siihen sisältyy muun muassa Gulag ${ }^{8}$-todistuksia. Tyypillisesti tämän ryhmän teokset ovat sävyltään isänmaallisia

5 Tällöin noin 18000 inkeriläistä karkotettiin pakkotyöhön Kuolan niemimaan kaivoksiin, Neuvostoliiton Karjalaan metsätyöhön tai Keski-Aasiaan. Karkotetut olivat enimmäkseen maanviljelijöitä, varakkaiksi arvioituja "kulakkeja", pappeja ja kirkon työntekijöitä sekä heidän perheenjäseniään tai muita kollektivisointeja vastustaneita henkilöitä. (Matley 1979.)

6 Tällöin pääsyynä karkotuksille oli Neuvostoliiton pyrkimys turvata raja-alueensa poistamalla sieltä poliittisesti epäluotettavat kansalaiset, mikä usein tarkoitti vähemmistöjä (Matley 1979).

7 Joidenkin teosten kohdalla rajanveto fiktion ja totuuspohjaisen teoksen välillä on vaikeaa.

8 Gulag-muistelmista ja niiden poliittisuudesta ks. Vettenniemi 2001, 34-35. Gulag on lyhennys Neuvostoliiton turvallisuuspoliisin NKVD:n rangaistustyöleirejä hallinneen viraston (Glavnoje upravlenije lagerei) nimestä. Sittemmin se laajeni Neuvostoliiton vankileiriverkoston yleisnimitykseksi. 
tai neuvostovastaisia, tai ainakin sellaisiksi myöhemmin tulkittuja. Tämän vuoksi osa niistä, kuten tässä artikkelissa tarkasteltava Juhani Konkan Kahden maailman rajalla (1939), joutui kielletyn kirjallisuuden listalle Suomessa jatkosodan jälkeen. Tähän ryhmään voidaan lukea myös esimerkiksi Aatami Kuortin (1934) ja Vilho Rantasen (1935) Gulag-todistukset. (Sihvo 1991, 328-330.)

Heti toisen maailmansodan jälkeen inkeriläisten kokemuksia koskevaa kirjallisuutta ei Suomessa julkaistu, koska Neuvostoliiton käsittely julkisuudessa oli rajoitettua (ks. Immonen 1987; Vettenniemi 2001). Stalinin kuoleman jälkeen 1950-luvun loppupuolella alkoi niin kutsuttu suojasään aika, johon ajoittuu inkeriläiskirjallisuuden toisen ryhmän muodostavien teosten julkaiseminen. Tähän ryhmään voidaan lukea muun muassa Juhani Konkan Pietarin valot (1958) sekä Johannes Angeren (1957) ja Oskar Himiläisen (1981) teokset. (Sihvo 1991, 330-336.) Osa ryhmään sijoittuvista teoksista on Ruotsiin muuttaneiden inkeriläisten kirjoittamia ja Ruotsissa julkaistuja.

Kolmas ja laajin inkeriläisten kokemuksia koskevan kirjallisuuden ryhmä koostuu Neuvostoliiton hajoamisen paikkeilla ja sen jälkeen julkaistuista teoksista. Verrattuna aiempaan kirjallisuuteen tätä ryhmää luonnehtii tendenssi keskittyä yksilön sisäiseen kokemusmaailmaan ja tunteisiin, joiden näkökulmasta myös politiikkaa, yhteiskuntaa ja ideologioita tarkastellaan. Tähän ryhmään voidaan lukea muun muassa Ella Ojalan (1988; 1990; 1994), Lyyli Ronkosen $(1989 ; 1990)$ ja Anita Konkan $(1985 ; 2001)$ teokset. (Sihvo 1990, 336-342.) Tämä muistelma-aalto voidaan nähdä osana laajempaa kansainvälistä "muistibuumia" eli uudenlaista kiinnostusta yksilöllisen ja kollektiivisen muistin rooliin yhteiskuntien nykyisyyden ja tulevaisuuden muotoilussa. Muistibuumin taustalla olivat muun muassa Neuvostoliiton sortumisen aiheuttama menneisyyden uudelleentulkinnan tarve, toisen maailmansodan tapahtumien käsittelyn tärkeyden uudenlainen korostaminen sekä uusi teknologia, joka mahdollisti menneisyyden käsittelytapojen ja aiheiden leviämisen globaalisti. (Erll 2011a, 1-5; Kõresaar, Kuutma ja Lauk 2009, 9-10; Levy ja Sznaider 2002; Huyssen 2003.)

\section{Moderni minä kertoo elämästään}

Läntisessä maailmassa kaksi keskeistä kehystä elämänkulun ja varttumisen esittämiselle ovat omaelämäkerran ja kehitysromaanin lajit. ${ }^{9}$ Näiden lajien suosion nousu kytkeytyy länsimaiseen modernisaation prosessiin, laaja-alaiseen ajatteluun, ihmiskäsitykseen ja yhteiskunnan rakenteisiin vaikuttaneeseen murrokseen. Modernin omaelämäkerran ja kehitysromaanin lajien on sanottu reflektoivan ja muotoilevan modernisaation arvomaailmaa ja ihmiskäsitystä, joihin liittyy subjektiivisuuden ja yksilön kehityksen merkityksen korostuminen (esim. Moretti 1987; Lejeune 1998, 13; Kosonen 2000, 15-19; Löschnigg 2005; Smith ja Watson 2010, 2-3).

Omaelämäkerta eli autobiografia on tekijän kertomus omasta elämästään. ${ }^{10}$ Omaelämäkerran määrittävinä kriteereinä on pidetty jatkuvuuteen perustuvaa (kertomus)muotoa, yksilön

9 Omakohtaisen kerronnan ja omaelämäkertojen tutkimus on monitieteistä. Suomessa omaelämäkertoja ja kirjoituksia omaelämäkertojen liepeillä on tutkittu kirjallisuudentutkimuksen lisäksi muun muassa folkloristiikan (esim. Savolainen 2015; 2016; 2017a; Hynninen 2017), etnologian (esim. Hytönen 2014), historian (esim. Taavetti 2018) ja kirjallistumisen historian (esim. Kuismin 2010) piirissä. 
elämään paikantuvaa aihetta, todellisuusviittaavuutta sekä retrospektiivisyyttä, joka edellyttää tekijän, päähenkilön ja kertojan samuutta. (Esim. Löschnigg 2005; Smith ja Watson 2001, 1-2; Lejeune 1989, 4.)11 Omaelämäkerrallinen subjekti sisältää kerronnan kohteena olevan, kerronnassa rakennetun minän sekä kertovan minän, joka omaelämäkerran tapauksessa on yhteydessä myös kirjoittajaan.

Lajin historiallinen perusta johdetaan tyypillisesti Augustinuksen noin vuoden 400 paikkeilla kirjoitettuun Confessiones-teokseen (Augustinus 1981, suom. Tunnustukset). Varsinaisen lajin, modernin omaelämäkerran, katsotaan kuitenkin muotoutuneen vasta $1700-l u v u n$ loppupuolella. Kerronnan jatkuvuuden ihanteeseen pohjautuvan modernin omaelämäkerran keskeinen teos on Jean-Jacques Rousseaun vuonna 1782 julkaistu Les Confessions (Rousseau 1891, suom. Tunnustuksia). Se noudattaa kehitykseen sekä syiden ja seurausten yhteyksiin perustuvaa tarinamallia. (Lejeune 1989, 13; Kosonen 2000, 15-19; Löschnigg 2005; Smith \& Watson 2010, 2-3.) Päivi Kososen mukaan rousseaulainen kertomuksen malli hallitsi omaelämäkertoja aina 1970-1980-luvuille saakka. Kuitenkin jo 1800-luvun puolivälissä modernin omaelämäkerran rinnalle alkoi kehittyä toinen, fragmentaarisuudelle pohjautuva tapa kirjoittaa omaelämäkertaa. (Kosonen 2000, 20-21; Löschnigg 2005.) 1960-luvulta lähtien poststrukturalistiset ja dekonstruktiiviset teoriat kyseenalaistivat varhaisemmat käsitykset omaelämäkerran jatkuvuudesta ja referentiaalisuudesta sekä subjektin eheydestä. Kritiikki ilmenee muun muassa autofiktion lajissa. Autofiktiolle tyypillinen piirre on yhtäältä fiktioksi julistautuminen ja toisaalta kuvattujen tapahtumien pohjautuminen tekijän elämään. (Koivisto 2005, 178-181; Zipfel 2005.)

Omaelämäkerta mielletään usein kirjoittajan oman elämänkulun retrospektiiviseksi kuvaukseksi, joka alkaa lapsuuden kuvauksesta. Lapsuuden käsittäminen keskeiseksi elämänvaiheeksi ja elämänkertomuksen osaksi on kuitenkin pikemminkin kulttuuri- ja aikasidonnaista kuin universaalia. Philippe Arièsin (1975 [1960]) sittemmin runsaasti kritisoidun väitteen mukaan lapsuuden käsittäminen aikuisuudesta erilliseksi ja siitä poikkeavaksi aikakaudeksi on läntisen maailman piiriin ja moderniin (keskiajan jälkeiseen) aikaan rajoittuva ilmiö. Ottamatta kantaa ajatukseen lapsuuden "keksimisestä" voidaan kuitenkin todeta, että lapsuuden merkityksen yhteiskunnallinen ja kulttuurinen painoarvo on kasvanut uudella tavalla 1700-luvun lopulta lähtien niin kutsutun modernisaatiokehityksen myötä (ks. Ahl beck et al. 2017, 2-6). Valerie Sandersin mukaan eurooppalaisissa omaelämäkerrallisissa teksteissä lapsuus nousi merkittäväksi aiheeksi vasta 1700-luvulta alkaen ${ }^{12}$ (Sanders 2001, 203-204). Peter Coveneyn mukaan lapset ja lapsuus oli poissaoleva aihe myös kaunokirjallisuudessa aina 1700-luvulle saakka (Coveney 1967 [1957], 29). ${ }^{13}$

Jean-Jacques Rousseaun ajatusten vaikutus modernin lapsuuden ideaan ja sen myötä lapsuuden omaelämäkerrallisiin ja kaunokirjallisiin esityksiin on ollut suuri. Rousseau korosti

on käyty runsaasti keskustelua elämää koskevien esitysten lajien määritelmistä ja niiden keskinäisistä suhteista. (Löschnigg 2005; Smith \& Watson 2001, 1-2; Kosonen 2000, 17.)

11 Philippe Lejeunen $(1989,4)$ kenties kuuluisamman omaelämäkerran määritelmän mukaan omaelämäkerta on retrospektiivinen proosamuotoinen todellisen henkilön kertomus elämästään ja persoonallisuutensa historiasta. Sittemmin Lejeunen määritelmää ja etenkin historiallisen totuuden vaadetta ja painotusta on kritisoitu voimakkaasti, vaikka kysymystä elämänkertomusten todellisuusviittaavuudesta ja sepitteellisyydestä on pidetty kiinnostavana (esim. Eakin 1992; ks. myös Gullestad 1996, 11-12). roissa kuvattiin lähinnä poikien tai pyhimysten lapsuutta (Sanders 2001, 203-204).

13 Lapsuuden kuvauksista kaunokirjallisuudessa myös esim. Scudder 1894; Pattison 1978; Kuhn 1982 ; Coe 1984. 
vuonna 1762 julkaistussa, poikien koulutukseen keskittyvässä teoksessaan ja kasvatusoppaassaan Émile ou de l'éducation (Rousseau 1904, suom. Émile eli kasvatuksesta) lapsen viattomuutta. (Poika)lapsen pahuuden syynä hän näki yhteiskunnan haitallisen vaikutuksen. Teoksessa pyrittiin ratkaisemaan kuinka ihmisestä kehittyisi paras mahdollinen kansalainen, vaikka yksilön (lapsen) luonnollisen itsekkäät halut ja tarpeet ovatkin ristiriidassa yhteisön tarpeiden kanssa. Émile-teosta on myös pidetty yhtenä ensimmäisistä kehitysromaaneista.

Klassisessa kehitysromaanissa (Bildungsroman) nuori mies lähtee pois kotoa maailmalle ja löytää epäonnistumisten, harhautumisten ja vastoinkäymisten jälkeen paikkansa yhteiskunnassa (Isomaa 2009, 21; Buckley 1974). Siinä korostetaan yksilöä ja yksilön kehitystä, mutta kuitenkin ympäröivän yhteiskunnan arvojen ja normien puitteissa (Burt 2001, 106). Kirjallisuudentutkija Franco Moretti on kutsunut kehitysromaania "moderniteetin symboliseksi muodoksi", sillä se toi romaanin keskiöön nuoren ja vasta kehittymässä olevan henkilöhahmon. Uudenlaisesta yhteiskunnallisesta, sosiaalisesta ja tilallisesta liikkuvuudesta johtuen tälle oli modernisoituvassa maailmassa erityinen tarve. (Moretti 1987, 5-6.) Kehitysromaanin ja modernin omaelämäkerran välillä on paljon yhteyksiä, mikä osin varmasti johtuu lajien kytkeytymisestä samaan historialliseen ja maailmankuvalliseen aikakauteen. Lajit noudattavat lineaarisen ja kronologisen elämän kuvaamisen logiikkaa ja ihannetta. Niille keskeistä on myös päähenkilön kasvun ja aikuistumisen esittäminen peruuttamattoman yksisuuntaisena kehityskulkuna lapsuudesta kohti aikuisuutta, joka merkitsee jonkinasteista sopeutumista yhteiskunnan normeihin. Elämä jäsennetään murroksiksi, jotka merkitsevät viattomuuden ja myyttisen alkutilan lopullista menetystä aikuistumisessa. (Smith ja Watson 2001, 101-102; Douglas 2010, 8; Kuhn 1982, 129.)

\section{Kahden maailman rajalla: yksilön ja yhteiskunnan murros}

Juhani Konkan vuonna 1939 julkaistu muistelmateos Kahden maailman rajalla lähenee

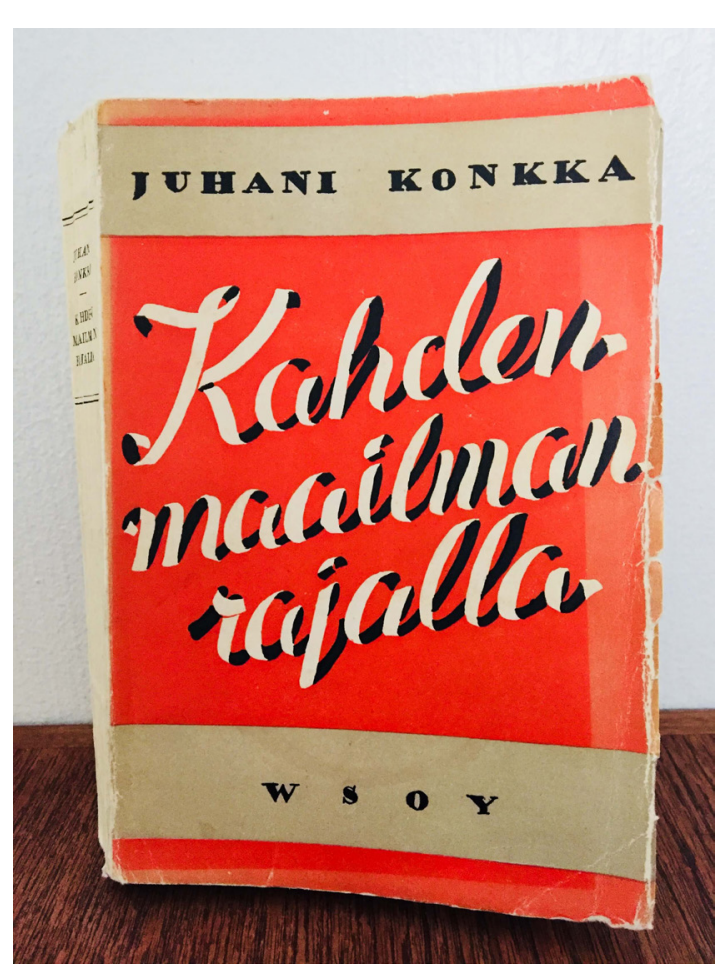

Kuva 1: Kahden maailman rajalla (1939). Valokuva: Ulla Savolainen. monella tapaa jännitysromaania. Teoksen alku paikantuu 20 kilometriä Pietarista pohjoiseen sijaitsevaan Toksovaan, jossa oli päähenkilö-kirjoittajan suhteellisen varakas talonpoikainen lapsuudenkoti. Tapahtumat alkavat vuodesta 1919, jolloin päähenkilö, Jussi tai Juho, on noin 14-vuotias. Kirja päättyy Tarton rauhan jälkeisiin tapahtumiin vuonna 1920. Teoksessa kuvataan neuvostosortoa, olojen kiristymistä ja mielivaltaisia vangitsemisia, jotka johtavat Konkan perheen vaiheittaiseen siirtymiseen pois Inkeristä ja perheen lopulliseen hajoamiseen. Ensin Konkan isä vangitaan, mutta hänen onnistuu paeta Suomeen. Tämän jälkeen Konkan äiti vangitaan, minkä jälkeen koko perhe päättää paeta Suomeen. Suomeen päästyään 15-vuotias Jussi ilmoittautuu vapaaehtoiseksi sotilaaksi Pohjois-Inkerin rykmenttiin, joka toimi Kirjasalossa. Neuvosto-Venäjän Tarton rauhassa antamien amnestialupausten myötä Jussin vanhemmat ja nuoremmat sisarukset päättävät palata Suomesta 
kotikylään Toksovaan, Inkeriin. Jussi sen sijaan päättää jäädä Suomeen. Teoksen viimeinen luku kuvaa kirjoittajan eroamisen perheestään Karjalankannaksella, Suomen ja Neuvosto-Venäjän rajalla.

Kahden maailman rajalla on nimensä mukaisesti murroksen ja siihen kytkeytyvän siirtymän kuvaus. Tämän lisäksi kahden maailman raja viittaa Inkerin ylirajaiseen asemaan suhteessa Suomeen ja (Neuvosto-)Venäjään. Inkerin asema kuvataan teoksessa ambivalenttina. Osana Venäjän aluetta Inkeri kuuluu itään, suomalaiseksi identifioituvan väestönsä kautta taas länteen. Konkan teoksessa murrosta artikuloidaan yhtäältä yhteiskunnallisena ja toisaalta yksilöllisenä taitekohtana, liminaalisena vaiheena, jota luonnehtii epävarmuus, pelko mutta myös mahdollisuus.

Ensinnäkin teos kuvaa yhteiskunnallista murrosta, johon ajoittuvat Inkerin, Suomen ja Neuvosto-Venäjän suhteiden ja rajojen määrittäminen, Venäjän sisällissota sekä erinäiset taistelut rajaseuduilla Virossa, Inkerissä ja Karjalassa. Murrokseen liittyvää epävarmuutta luonnehtii toive Inkerin valoisammasta ja vapaammasta tulevaisuudesta joko itsenäisenä tai osana Suomea tai demokraattista Venäjää sekä pelko bolševistisen yhteiskuntajärjestyksen vakiintumisesta Inkerissä. Epävarmuus tulee teoksessa esiin muun muassa lokakuun vallankumouksen jälkeisen tunnelman kuvauksessa Jussin kotikylässä Inkerissä:

"Suomi tulloo, Suomi tulloo", puhui silloin kansa odottaessaan apua ja pelastusta Suomen taholta, ja kun sinä keväänä jokin tähti - luultavasti Venus - nousi kirkkaana jo ennen auringon mailleen menoa taivaalle, niin yksinkertaiset ihmiset väittivät sen olevan raketin, jolla Suomesta ilmoitettiin Inkerin kansalle kohta alkavasta hyökkäyksestä Pietariin. Muistakin merkeistä ennustettiin Suomen tuloa: kahdesta oravasta, jotka olivat jostakin syystä eksyneet Setälän suurimpaan pihlajaan, maamyyrästä, joka juoksi poikki maantien, ja hännättömästä vasikasta, jonka synnytti Metsä-Mikon Mansikki. (Konkka 1939, 9-10.)

Katkelma kuvaa liminaalitilan ambivalenssia, johon sisältyy Suomen tuloon ja Inkerin vapauttamiseen liittyvää optimistista toiveikkuutta mutta myös epävarmuutta ja pelkoa tulevasta. Konkka kuvaa tämän epävarmuuden hallintaa kotikylänsä "yksinkertaisten ihmisten" menetelmien näkökulmasta. He tulkitsevat taivaankappaleiden ja eläinten epätavallisen käyttäytymisen yhteiskunnallisen murroksen ennusmerkeiksi. Kun katkelmaa luetaan modernin omaelämäkerran ja kehitysromaanin lajien lineaarisen logiikan näkökulmasta, se on kuvaus Inkerinmaasta ja sinne paikantuvasta elämästä esimodernina. Ne sijoittuvat menneisyyteen, kehityksen alkupisteeseen. Tähän menneisyyden maailmaan paikantuu teoksessa myös kirjoittaja-päähenkilön lapsuus.

Yhteiskunnallisen murroksen lisäksi Kahden maailman rajalla kuvaa murrosta yksilön elämässä - lapsuuden loppumista ja kasvua. Lapsuutta edustavat Jussin naiivi ihanteellisen rakkauden kaipuu sekä haaveet sotasankaruudesta ja suurtöistä. Lapsuuden attribuutteina teoksessa ovat viattomuus ja epärealistisuus, joita kuvataan muun muassa nuoren Jussin sotasankaruuskuvitelmien kautta: "'Te olette luutnantteja ja minä vain kyytipoikanne, mutta vartokaahan parisen viikkoa, silloin olen minäkin luutnantti, kukaties jo kapteeni'. 'Voin olla everstikin', - ajattelin jo hetken kuluttua." (Konkka 1939, 258.) Teoksen päähenkilön, nuoren Jussi Konkan, vakaumus on kirkasotsaisen optimistinen. Päähenkilö uskoo asiat parhain päin. Hän uskoo, että Inkeri vapautuu bolševismin ikeestä Suomen ja hänen omien sotasaavutustensa avulla. Sodan kokemus tuhoaa kuitenkin lapsen unelmat sankaruudesta: 
Katselin haavoittuneita hyvin vakavana, Vasta nyt, ensimmäistä kertaa elämässäni, näin edessäni osan sodan varsinaista todellisuutta. Tähän asti en milloinkaan ajatellut, että sotaan kuuluvat myös haavat, kalpeat kasvot, tuskaiset valitukset ja veriset siteet. Olin nähnyt sodan mielikuvituksessani ylevänä, jalona kamppailuna, jossa urheat sankarit hyökkäävät eteenpäin miekka tai pistooli kädessä, sotalipun hulmutessa ja eläköön-huutojen kaikuessa. (Konkka 1939, 262.)

Kokemus yhtäältä sodan raakuudesta ja toisaalta sen banaaliudesta sekä pettymys Suomen lojaaliuden puutteeseen ilmentävät teoksessa aikuistumista: kasvu merkitsee lapsuuden poliittisen optimismin korvautumista pessimismillä Inkerin ja inkeriläisten vapaan tulevaisuuden suhteen. Tätä murrosta symboloi teoksessa myös päähenkilön päätös jäädä Suomen puolelle Tarton rauhan jälkeen. Varttunut päähenkilö ei usko mahdollisuuteen jatkaa elämäänsä Inkerissä, sillä toiveista huolimatta Inkeri jää osaksi Neuvosto-Venäjää.

Modernin omaelämäkerran ja kehitysromaanin suoraviivaisen kehityksen mallin näkökulmasta menneisyyttä ja lapsuutta seuraa luonnollisesti aina nykyisyys ja aikuisuus sekä myös tulevaisuus. Menneisyyden ja nykyisyyden välisestä selkeästä erosta huolimatta kehitys ja sen myötä tulevaisuus ovat mahdollisia ainoastaan, mikäli menneisyyden ja nykyisyyden välillä on yhteys. Konkan Kahden maailman rajalla -teos ilmentää tämänkaltaista menneisyyden ja nykyisyyden välisen suhteen logiikkaa kuvatessaan lapsuutta ja kasvua. Lapsuuden maailma kuvataan onnelliseksi, vilpittömäksi mutta myös naiiviksi esimoderniksi maailmaksi, joka katoaa aikuistumisen, kasvun ja modernisaation myötä. Kehityksen merkitys onkin ambivalentti. Vaikka menneisyys (ja lapsuus) näyttäytyy näiden lajien näkökulmasta tyypillisesti luonnollisempana ja intuitiivisempana kuin nykyisyys (ja aikuisuus), merkitsee kehitys myös syvempää tietoisuutta. Ennen kaikkea kehitys on välttämätöntä ei ainoastaan nykyisyyden vaan myös tulevaisuuden kannalta.

Teoksen lopussa, kun kuvitelmat Inkerin itsenäistymisestä ovat kumoutuneet, päähenkilö-Konkka päättää siirtyä pysyvästi Suomeen. Hänen vanhempansa sen sijaan palaavat Inkeriin, joka jää osaksi Neuvosto-Venäjää. Nuoren Konkan päätös jäädä Suomeen merkitsee lapsuuden loppua, kasvua ja eroa lapsuudenperheestä. Inkeri ja Inkerissä olo rinnastuvat teoksessa lapsuuteen, viattomuuteen ja idealismiin, kun taas sieltä poissaolo rinnastuu varttumiseen, ihanteiden ja kuvitelmien haihtumiseen sekä todellisuuden banaaliuteen. Vaikka Inkeri ja sen kautta myös Venäjä jäävät edustamaan lapsuutta ja menneisyyttä, ei päähenkilön asemoituminen suhteessa niihin ole yksiselitteinen, vaan pikemminkin ylirajainen:

Minä horjuin kahden maailman, Suomen ja Venäjän, lännen ja idän välillä, ja sellaisena horjuvana jäin seisomaan rajan tälle puolelle, kunnes sitten vähitellen, vuosien mittaan opin ymmärtämään, että päätökseni jäädä oli ollut oikea (Konkka 1939, 358).

Samaan tapaan kuin menneisyyden ja nykyisyyden tai lapsuuden ja aikuisuuden suhde on ambivalentti, myös päähenkilön asemoituminen suhteessa Inkeriin, Suomeen ja Venäjään näyttäytyy teoksessa ennen kaikkea ylirajaisena ja epävarmana. Myös Inkerin asema suhteessa Suomeen ja Venäjään määrittyy ylirajaiseksi ja häilyväksi. Katsonkin, että lineaarisen kehityksen logiikalle sekä kehityksen ambivalenssille perustuvina muotoina modernin omaelämäkerran ja kehitysromaanin lajit toimivat resursseina, joiden avulla jäsennetään yksilön kasvun ja kehityksen lisäksi myös ylirajaista asemoitumista. Kahden maailman rajalla -teoksessa modernin omaelämäkerran ja kehitysromaanin kehykset osallistuvat yksilön kasvun teeman kautta myös asemoitumisen neuvotteluun suhteessa Inkeriin, Suomeen ja Venäjään. 
Tämä ilmentää olennaisesti modernia tapaa hahmottaa yksilön ja kollektiivin suhdetta kansallisen kuulumisen ja sen pohtimisen kautta.

\section{Pietarin valot: paikka ja sukupolvinen muutos}

Vuonna 1958 Juhani Konkalta ilmestyi muistelmateos Pietarin valot, joka oli Kahden maailman rajalla -teoksen uudistettu versio. Alkuun Konkka on lisännyt Inkeriin sijoittuvan varhaisemman lapsuutensa kuvauksen ja loppuun kuvauksen Inkerinmaan muutoksesta sen jälkeen, kun hän siirtyi Suomeen vuonna 1919. Laajennetuissa osissa Konkka ei kuvaa elämäänsä Suomessa, vaan vierailuja Inkerissä. Verrattuna Kahden maailman rajalla -teokseen, jonka keskiössä on lyhyt ajanjakso sekä yhteiskunnallinen ja yksilöllinen murros, Pietarin valot on kuvaus yksilön kehityksestä ja elämästä sekä sukupolvisesta muutoksesta pidemmällä aikaperspektiivillä. Teoksessa kehitystä ja muutosta artikuloidaan nimenomaan suhteessa Inkerinmaahan.

Kuten nimi viittaa, Pietarin kaupungilla on keskeinen rooli muistelmateoksessa. Ensimmäisessä luvussa Konkka kuvaa,

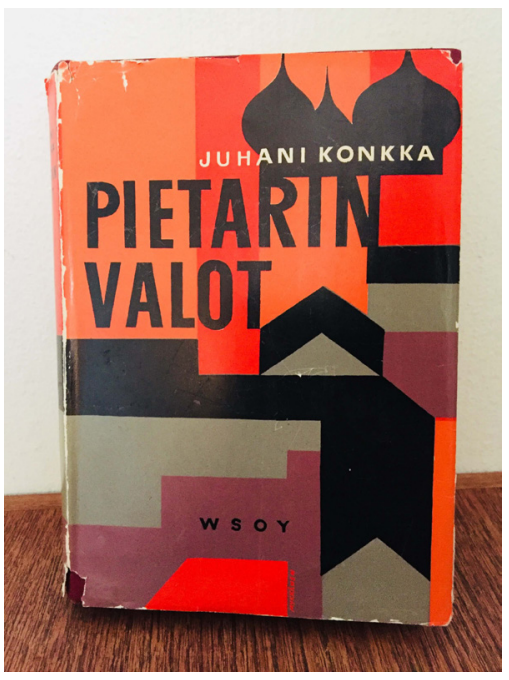

Kuva 2: Pietarin valot (1958). Kuva: Ulla Savolainen kuinka hän alkoi kiivetä kotinsa pihapuihin nähdäkseen Pietariin:

Päivällä, mikäli aurinko sattui paistamaan, näin eteläisellä taivaanrannalla, minne katseeni aina suuntautui, joidenkin kirkkojen kullattuja sipulikupoleja, illalla sen sijaan pitkän rivin valoja, ja ne kiihottivat kummasti mielikuvitustani, vetivät minua oudosti puoleensa, herättivät haluja ja toiveita; kaikki kuulemani sadut prinsessoista, prinsseistä ja kuninkaista yhdistin noiden valojen vaiheille.

Mutta äitini ei sallinut minun haaveilla siellä koivussa kovinkaan kauan. Hilma-siskoni, joka oli minua vuotta vanhempi, meni tavallisesti sanomaan äidille, että olin jälleen puussa, ja äiti tulikin tuota pikaa huutamaan minulle:

- Alas sieltä, russoolainen, heti paikalla alas! Enkö ole sanonut sinulle sata kertaa: putoat vielä ja taitat niskasi! (Konkka 1958, 7.)

Kuvauksessa päähenkilö-Konkka "russoolaisena" kurittomana lapsena tarkastelee Pietaria sen kyljessä sijaitsevasta kotikylästään käsin. Pietaria ei kuvata niinkään keskeisenä tapahtumapaikkana kuin lapsen katseen, unelmien, pelkojen ja vierailujen kohteena, joka tuntuu samaan aikaan läheiseltä ja vieraalta. Etäisyys kotikylästä kiehtovaan metropoliin rinnastuu lapsuuden ja aikuisuuden välimatkaan, jota myös kasvu ilmentää. Myös paikkojen välinen suhde rinnastuu lapsuuden ja aikuisuuden suhteeseen: kotikylä edustaa lapsuutta ja Pietari lapsen kuvitelmaa aikuisuudesta.

Kasvuun sekä paikkojen suhteisiin liitetyt merkitykset ovat teoksessa ambivalentteja. Pietari ei symboloi niinkään tavoiteltavissa olevaa todellisuutta, vaan pikemminkin nuoren Konkan unelmia ja epärealistista kuvitelmaa tulevaisuudesta, vaikka sillä on myös mahdollisuus edistää kasvavan nuoren miehen kehittymistä modernisoituvaan maailmaan sopeutuvaksi 
yksilöksi. Tätä paikkaan ja kasvuun liittyvää ambivalenssia kuvataan myös Konkan äidin hahmon kautta, jolle Pietari edustaa ennen kaikkea uhkaa totutulle elämäntyylille:

\begin{abstract}
Koti, lapset ja omaiset - siinä koko äidin maailma. Pitkiä vierailumatkoja hän ei tehnyt, ja Pietariinkin isä sai hänet lähtemään välttämättömille ostoksille korkeintaan kerran viidessä vuodessa. - Enhän minä sinne, hän sanoi, - siellä on niin paljon hälinää ja kolinaa, että ihan menevät korvat lukkoon, ei minua se linna houkuttele puoleensa. Ja jätä sinäkin, Junu, hän kääntyi minun puoleeni, - kiipeileminen koivuun ja tiiraileminen niihin linnan valoihin. Ei niiden valojen ympärillä liehu muuta kuin pahuus ja huoruus. (Konkka 1958, 18.)
\end{abstract}

Kasvun teemaa laajeneekin Pietarin valoissa käsittämään myös sukupolvien välisen muutoksen. Nuoren Konkan isän hahmo edustaa teoksessa muutoksen nivelkohtaa, linkkiä menneisyyden ja nykyisyyden, esimodernin ja modernin maailman välillä. Menneisyyden maailmaa edustaa Konkan äidin hahmo ja nykyisyyttä Konkka itse. Konkan isä kuvataan tyypilliseksi talonpoikaiseksi edelläkävijäksi, yhteisön luottohenkilöksi, joka arvostaa sivistystä ja rationaalista maailmankuvaa sekä toivoo yhteiskunnallisia uudistuksia tsaarin Venäjälle ja sen myötä myös Inkeriin. Konkka kuvaa isänsä uskonnottomaksi vapaa-ajattelijaksi, joka luettuaan Rousseaun Émile-teoksen juuri ennen Jussi-pojan syntymää halusi, lapsen äidin vastusteluista huolimatta, kasvattaa lapsensa vapaan kasvatuksen oppien mukaan. Nuoren itsensä Konkka kuvaa minuutensa ja tahtonsa tiedostavaksi, ristiriitaiseksi moderniksi yksilöksi, joka on kehittynyt konservatiivisen äidin ja uudenaikaisen isän kasvatusperiaatteiden ristipaineessa.

Toisin kuin Kahden maailman rajalla -teoksessa, Pietarin valoissa Konkan "russoolaisuus" ja siihen kytkeytyvä jännite perheen jäsenten välillä tuodaan korostetusti esiin jo aivan kirjan alussa. Tämä kehystää teoksen kuvaukseksi yksilön kasvusta sekä sukupolvien välisestä muutoksesta. Maininnat "russoolaisesta" lapsuudesta ovat suoria intertekstuaalisia viittauksia Rousseaun Émile-teokseen (1762). Nuoressa Konkassa "russoolaisuus" merkitsee yhtäältä kurittomuutta ja tietynlaista sopeutumattomuutta, mutta toisaalta myös oppimishalua ja kykyä itsenäiseen ajatteluun. Tätä jännitettä ilmaistaan eri hahmojen kautta. Konservatiivisen äidin näkökulmasta "russoolaisuus", aivan kuten Pietarin kaupunki, merkitsee uhkaa hänen (esimodernille) maailmalleen, mutta Konkalle itselleen "russoolaisuus" on ylpeyden aihe, vaikka se merkitsee erillisyyttä äidin ja menneisyyden maailmasta. Suoralla viittauksella Rousseaun teokseen päähenkilö-Konkka rinnastetaan myös kehitysromaanien päähenkilöihin, jotka kasvavat lapsuuden viattomuudestaan ja itsekeskeisyydestään psykologisesti ja tietoisuudeltaan kypsiksi sekä aikuisiksi yksilöiksi. Kasvu merkitsee samaan aikaa sekä subjektin sisäisen maailman kypsymistä että lapsuuden viattomuuden peruuttamatonta menetystä.

Muistelmien julkaisuajankohtien väliin ajoittuu kokemuksia, joita Konkka käsittelee vain Pietarin valot -teoksessa. Tästä johtuen päällekkäiset kuvaukset lokakuun vallankumouksen jälkeisestä ajasta asettuvat kirjoissa erilaisiin asemiin ja saavat erilaisia merkityksiä. Vuonna 1939 julkaistun Kahden maan rajalla -teoksen lukijat tietävät Inkerin ja inkeriläisten kohtalosta 1930-luvun Neuvostoliitossa. Inkerin ylirajaiseen positioon kytkeytyvä uhka jää kuitenkin tarinamaailman tasolla avoimeksi, kun teos päättyy Konkan päätökseen jäädä Suomeen perheen palatessa Inkeriin. Pietarin valot -teoksessa uhka sen sijaan aktualisoituu myös tarinamaailman tasolla loppuun sijoitettujen uusien osien kautta. Nämä osat kuvaavat Suomeen asettuneen aikuisen Juhani Konkan myöhempiä vierailuja Inkerissä. Ensimmäinen vierailuista, salaa tehty matka kotikylään, ajoittuu vuoteen 1923 eli kolmen vuoden 
päähän Konkan ja hänen perheenjäsentensä erosta. Inkerissä perhe elää köyhyydessä. Isä on vangittu useita kertoja, äiti on sairastanut ja perhe on köyhtynyt, kun entisiä maita ei saatu takaisin. Yllätys Konkalle on kuitenkin se, että kaksi hänen sisaruksistaan ovat "kääntyneet" kommunisteiksi ja kuuluvat komsomoliin. He jopa uhkaavat ilmiantaa hänet, valkobandiitin. Myös isässä on tapahtunut muutos. Hän arvioi "russoolaisia" kasvatusperiaatteitaan sekä entistä vapaa-ajatteluaan kriittisesti. Isä myös tunnustaa Juhanille kääntyneensä kristilliseen uskoon. Konkka kuvaa muutosta perheenjäsenissään toisaalta järkytyksen kautta, toisaalta samastaen sisarustensa idealismin omaan, aiempaan idealismiinsa vapaasta Inkeristä:

\begin{abstract}
Katsellessani Eeroa minusta vaikutti siltä kuin olisin tarkkaillut itseäni, mutta seitsemän vuotta nuorempana. Rakenteeltamme ja kasvojemme piirteiltä olimme jokseenkin samanlaiset, ainoastaan Eeron kulmakarvat eivät yhtyneet nenän juuressa niinkuin minun. Peräti tuttua oli minulle tuo kiivailukin. Itse kuljeskelin kolmetoistavuotiaana täällä kotiseudulla vaaliagitaattorina ja puhuin kaikkein tulisimmin bolsevikkien listaa vastaan. Minulla oli silloin syvä vakaumus, että esiinnyin oikean asian puolesta, Eerolla oli nyt oma vakaumuksensa. (Konkka 1958, 334.)
\end{abstract}

Jonkinasteisesta ymmärtämisestä huolimatta Konkka poistuu Inkeristä haikean pessimistisissä tunnelmissa todeten, ettei koskaan sen jälkeen enää nähnyt kotiaan eikä omaisiaan. Kun Konkan rinnastusta veljensä ja oman nuoruuden idealisminsa välillä tulkitaan suhteessa rousseaulaiseen ideaan kasvusta ja kehitysromaanin lajiin, siitä avautuu uudenlaisia merkityksiä. Myös tässä kasvun teemaa luonnehtii ambivalenssi. Rinnastuksen kautta Konkka kuvaa itsensä psykologialtaan, moraaliltaan sekä käsityskyvyltään aikuiseksi, joka on jättänyt lapsuuden ja nuoruuden viattoman idealismin taakseen. Veli taas kuvataan edelleen lapsuuden keskeneräiseen tilaan, epärealismiin mutta myös optimistiseen uskoon, joka kuitenkin lopulta koituu hänen haitakseen. Kyseessä on voimakas kannanotto Konkan tekemien elämänvalintojen ja ennen kaikkea Suomeen siirtymisen puolesta, mutta asettelua voidaan tulkita myös negatiivisena arviona Neuvostoliitosta ja sen poliittisen järjestelmän tilasta.

\title{
Kahden nykyisyyden muisti
}

Konkan muistelmien ilmestymisvuosien (1939 ja 1958) välillä on lähestulkoon parikymmentä vuotta aikaa, mikä tekee niistä erityisen kiinnostavan tapaustutkimuksen kulttuurisen muistin näkökulmasta. Julkaisuajankohtien väliin ajoittuvat muun muassa Suomen ja Neuvostoliiton välillä käydyt talvi- ja jatkosota sekä niitä seurannut murros maiden suhteissa. Teosten kontekstualisointi julkaisuajankohtaansa mahdollistaa tulkintojen tekemisen siitä, minkälaisista nykyisyyksistä käsin ne esittävät, tulkitsevat ja hyödyntävät menneisyyttä eli tuottavat kulttuurista muistia. Tämän lisäksi Juhani Konkan kirjoittamiseen liittyvistä motiiveista voidaan tehdä tulkintoja muistelmien alku- ja loppusanojen analyysin kautta. Nämä teosta kehystävät kynnys- eli paratekstit (Genette 1997) tarjoavat tietoa teoksen tulkinnan ja sen ymmärtämisen taustaksi.

Kahden maailman rajalla -teoksen alkusanoissa Juhani Konkka selittää syitä muistelmateoksen kirjoittamiselle:

Lähdettyäni viime elokuun alussa linnoitustyömaalta matkustelin Kannaksella katselemassa niitä paikkoja, joilla olin viimeksi liikuskellut lähes kaksikymmentä vuotta sitten. Kovassa ruumiillisessa työssä, reippaiden lapiojääkärien seurassa hankittu virkeä mieliala ja tuttujen paikkojen näkeminen innoittivat minua jatkamaan tätä toden ja kuvitelmien sarjaa, jonka olin aloittanut jo kaksi vuotta sitten. 


\begin{abstract}
Omistan kirjan Siperiassa karkoitettuna kuolleen isäni muistolle, samoin kuin niiden tuhansien inkeriläisten muistolle, jotka lepäävät tuntemattomissa haudoissaan Hiipinässä, Siperiassa ja Turkestanissa.

Helsingissä, syyskuun alussa 1939.

Tekijä. (Konkka 1939.)
\end{abstract}

Omistuskirjoitus Siperiaan karkotetun ja siellä kuolleen isän muistolle on keskeinen tulkittaessa Konkan kirjoittamisen motiiveja sekä tapaa, jolla hän toivoisi muistelmiaan luettavan. Vaikka Kahden maailman rajalla kuvaa ainoastaan neuvostohallinnon harjoittaman vainon alkuvaiheita vuosina 1919-1920 sivuuttaen pitkälti karkotukset ja vankileirikokemukset, asettaa Konkka alkusanoissaan teoksensa vähintään epäsuorasti myöhempiä vankileiri- ja karkotuskokemuksia kuvaavan Gulag-kirjallisuuden joukkoon. Olennaista tämän tulkinnan kannalta on myös se, että alkusanoissa Konkka mainitsee aloittaneensa muistelmien kirjoittamisen kaksi vuotta aiemmin eli vuonna 1937, joka tunnetaan Stalinin vainojen huipentumisen vuotena.

Myös historiallinen kontekstualisointi tukee tätä tulkintaa. Suomalaisia Gulag-muistelmia tutkinut Erkki Vettenniemi on todennut, että neuvostovastaisuus leimasi ideologista ja poliittista ilmapiiriä 1930-luvun Suomessa, myös kirjallisuudessa, ja että Suomessa tiedettiin 1930-luvulla esimerkiksi inkeriläisten kohtalosta (Vettenniemi 2001, 34-35; ks. myös Immonen 1987; Luostarinen 1986, 184). Suomen itsenäistymisen jälkeen kansakunnan ideaa rakennettiin Vettenniemen mukaan suhteessa Neuvostoliittoon ja sen uhkaan. Suomi olikin suotuisa ympäristö neuvostosorron, kuten vankileirikokemusten, kuvauksille. (Vettenniemi 2001, 34-35, 39.) Epäilemättä myös Konkan Kahden mailman rajalla -teosta luettiin 1930luvun lopun Suomessa suhteessa tietoihin Neuvostoliiton vankileireistä ja inkeriläisten laajamittaisesta sorrosta, joka alkoi 1920-luvun lopulla ja huipentui 1930-luvun jälkimmäisellä puoliskolla (Matley 1979, 9-10). Teos voidaan paikantaa osaksi Neuvostoliittoa negatiivisesti kuvaavaa kirjallisuutta. Se tuottaa historiakuvaa lokakuun vallankumouksen jälkeisestä Neuvosto-Venäjästä, Inkerinmaasta ja kirjailijan omista kokemuksista 1930-luvun Neuvostoliiton uhkaa pelkäävässä ja neuvostovastaisessakin Suomessa. Tästä näkökulmasta yksilön kasvun, yhteiskunnan murroksen ja Inkerin aseman pohdinta näyttäytyy myös kommentaarina Suomen talvisotaa edeltävään tilanteeseen, jossa rakennetaan linnoituksia itärajalla. Inkerin kohtalo osana Neuvostoliittoa ja inkeriläisten kohtalo Neuvostoliitossa suomalaisina ovat varoittavia esimerkkejä Suomelle.

Myös Pietarin valot -teokseen sisältyy kynnysteksti, jossa Konkka tarjoaa lukijalle tietoa teoksen tulkinnan tueksi. Jälkisanassa Konkka kirjoittaa:

Niinkuin tuotantooni perehtynyt lukija on voinut havaita, tässä kirjassa kerrotaan osaksi samoista asioista kuin talvisodan kynnyksellä ilmestyneessä ja sittemmin "kiellettyjen kirjojen" listalle merkityssä teoksessani "Kahden maailman rajalla". Alku ja loppu ovat uutta tekstiä. Herätteen vanhan kirjan laajentamiseen ja muokkaamiseen antoi viime keväänä kotiseudulleni Inkeriin tekemä matka.

Kotkanpesä, lokakuussa 1958.

Tekijä (Konkka 1958.)

Elore (ISSN 1456-3010), vol. 25 - 2/2018. Julkaisija: Suomen Kansantietouden Tutkijain Seura ry. 
Jälkisanassa Konkka kytkee Pietarin valot -teoksen eksplisiittisesti Kahden maailman rajalla -teokseen, jonka hän myös mainitsee joutuneen kiellettyjen kirjojen listalle. Kiellettyjen kirjojen lista viittaa neuvostovastaiseksi tulkittuun kirjallisuuteen, jonka Neuvostoliiton valvontakomissio määräsi jatkosodan jälkeen poistettavaksi lukijoiden saatavilta Suomessa (ks. Ekholm 2000). Jälkisanan kautta teos, joka julkaistiin Stalinin kuolemaa seuranneen niin sanotun suojasään aikana, kommentoi jälkiviisaudella jatkosodan jälkeisiä tapahtumia. Se myös alleviivaa, että Kahden maailman rajalla -teoksessa esitetty pelko Neuvostoliittoa kohtaan oli aiheellinen. Kulunut aika on osoittanut sen, että uhkakuvat Inkerin ja inkeriläisten kohtalosta Neuvostoliitossa ovat monilta osin toteutuneet. Tätä Konkka tuo esiin myös Pietarin valot -teoksen viimeiseen lukuun sijoitetussa kuvauksessa vuonna 1958 tekemästään matkasta kotiseudulleen Inkerin Toksovaan, jonne hän saapui Neuvostoliittoon kutsuttuna vieraana, kirjailijoiden seurassa. Viimeisessä luvussa Konkka kertoo myös perheensä kohtalosta. Vuonna 1930 hänen vanhempansa oli karkotettu Siperiaan. Äiti ja lapset pääsivät lähtemään sieltä parin vuoden päästä pois, joskaan eivät kotiseuduilleen. Isä sen sijaan siirrettiin Jakutiaan, jossa hän kuoli. Myös Konkan kotikylä Inkerissä oli hävitetty. Kuvauksen tunnelma on haikea, kun Konkka ymmärtää lapsuutensa loppuneen ja lapsuuden maailman, Inkerin, lopullisesti kadonneen.

\section{Lopuksi}

Olen tässä artikkelissa käsittellyt kasvun teemaa ja ylirajaisuutta Juhani Konkan kahdessa muistelmateoksessa Kahden maailman rajalla ja Pietarin valot kulttuurisen muistin näkökulmasta. Olen lukenut teoksia suhteessa modernin omaelämäkerran ja kehitysromaanin lajeihin. Olen tarkastellut myös sitä, miten historian tapahtumien ja omakohtaisten kokemusten merkitykset ilmentävät teosten kohdalla kahden erilaisen nykyhetken, vuosien 1939 ja 1958, muistia. Näiden lisäksi olen pohtinut sitä, miten erilainen kehystys vaikuttaa samoille historiallisille tapahtumille ja kokemuksille annettuihin merkityksiin. ${ }^{14}$

Huolimatta siitä, että Konkan kahdet muistelmat sisältävät paljon identtisiä osia, ne ovat pikemminkin itsenäisiä teoksia kuin versioita samasta teoksesta. Vuonna 1939 ilmestynyt Kahden maailman rajalla kuvaa yhteiskunnassa ja yksilön elämässä tapahtunutta murrosta, jota leimaa liminaalitilan ambivalenssi ja epävarmuus. Murrosta artikuloidaan ensinnäkin yhteiskunnallisena taitekohtana, joka ilmenee Inkerin, Suomen ja Neuvosto-Venäjän suhteiden ja rajojen määrittämisenä sekä erilaisina taisteluina Venäjällä ja rajaseuduilla. Toiseksi murrosta artikuloidaan yksilön elämän taitekohtana, lapsuuden loppumisena ja kasvuna. Vuonna 1958 ilmestyneen Pietarin valot -teoksen tapahtumat sijoittumat pidemmälle aikavälille ulottuen varhaisemmasta lapsuudesta aina aikuisuuteen. Kirja kuvaa yksilön elämää, mutta tekee sen suhteessa Inkerinmaahan. Siinä Inkerin kotikylän ja Pietarin metropolin välinen suhde rinnastuu lapsuuden ja aikuisuuden suhteeseen: kotikylä ilmentää lapsuuden maailmaa ja Pietarin kaupunki lapsen kuvitelmaa aikuisuuden mahdollisuuksista. Kasvun teema merkitsee Pietarin valot -teoksessa myös sukupolvista muutosta.

14 Analyysia olisi ollut mahdollista täydentää tarkastelemalla Juhani Konkan teosten lisäksi hänen tyttärensä, Anita Konkan, elämäkertaromaania Johanneksen tunnustukset (1995). Arkistoaineistoja, päiväkirjoja ja fiktion keinoja hyödyntäen Anita Konkka tulkitsee isänsä menneisyyttä tyttären näkökulmasta. Tämän artikkelin kannalta kiinnostava on ainakin teoksen nimi, joka viittaa Rousseaun (Tunnustuksia) ja Augustinuksen (Tunnustukset) teoksiin sekä kenties myös Jean-Jacques Rousseaun nimeen. 
Juhani Konkan muistelmateokset argumentoivat ja rakentuvat ennen kaikkea rinnastusten kautta. Elämäkerrallinen lapsuuden ja aikuisuuden kontrasti on teosten ydinrinnastus, jonka kautta argumentoidaan tilallisten ja yhteiskunnallisten rinnastusten merkityksiä. Teoksissa modernin omaelämäkerran ja kehitysromaanin lajit osallistuvat yksilön kasvun teeman kautta neuvotteluun Inkerin ylirajaisesta positiosta. Päähenkilön kasvu rinnastuu Inkerinmaan ja inkeriläisten elämän historialliseen muutokseen - paikat, maantieteelliset siirtymät, yhteiskunnalliset murrokset sekä henkilön muutos nivoutuvat yhteen. Lajit ovat kulttuurisen muistin resursseja. Ne ilmentävät ja tuottavat kulttuurista muistia välittäessään jaettuja tapoja ymmärtää yksilön elämää ja sen suhdetta kollektiiviseen muutoksen, kansallisten kehysten sekä niihin liittyvän ambivalenssin kautta. Konkan muistelmateokset kommentoivat kirjoitushetkien keskeisiä poliittisia ja yhteiskunnallisia kysymyksiä, kuten inkeriläisten asemaa sekä Inkerin, Suomen ja Neuvostoliiton suhteita, kulttuurissa vakiintuneiden mallien ja keinojen puitteissa.

Kulttuuriset käsitykset lapsuuden ja aikuisuuden suhteesta sekä kehityksestä ja kasvusta liittyvät myös laajempiin sosiaalisiin, yhteiskunnallisiin ja historiallisiin ilmiöihin, kuten modernisaatioon. Kulttuurisessa muistissa on kyse aihelmien, kehysten ja mallien kierrätyksestä, muuntelusta ja lainaamisesta nykyhetken tarpeisiin, niiden mukanaan kantamia merkityksiä soveltaen. Samaan aikaan kun Konkka hyödyntää modernin omaelämäkerran ja kehitysromaanin poeettisia piirteitä ja käsitystä maailmasta omiin tarkoituksiinsa, lajit väistämättä myös ohjaavat Konkan teosten tapaa jäsentää lapsuutta, aikuisuutta ja kasvua. Puhtaan lapsuuden menettämisen haikeudesta huolimatta aikuisuus artikuloidaan ihmiselämän kehityksen luonnollisena, välttämättömänä ja siten myös tavoiteltavana tuloksena. Lajien voidaankin nähdä kantavan ja tuottavan Konkan teoksissa tietynlaista muistia, tulevaisuusorientoitunutta käsitystä menneisyyden ja nykyisyyden suhteesta. Vaikka lapsuuteen Inkerissä kohdistuu Konkan teoksissa lämpöä ja kaihoakin, ei menneisyyttä pyritä saamaan takaisin eikä nykyisyyttä ja tulevaisuutta määrittäviä menneitä valintoja kaduta. Muutos ja sitä määrittävät valinnat kuvataan väistämättöminä.

\section{Lähteet}

\section{Tutkimusaineistot}

Konkka, Juhani. 1939. Kahden maailman rajalla. Porvoo: Werner Söderström Osakeyhtiö. Konkka, Juhani. 1958. Pietarin valot. Porvoo: Werner Söderström Osakeyhtiö.

\section{Kirjallisuus}

Ahlbeck, Jutta, Päivi Lappalainen, Kati Launis ja Kirsi Tuohela. 2017. "Introduction: Child Figures as Fragile Subjects". Teoksessa Childhood, Literature and Science: Fragile Subjects, toimittaneet Jutta Ahlbeck, Päivi Lappalainen, Kati Launis ja Kirsi Tuohela, 1-19. Milton: Taylor \& Francis Group.

Angere, Johannes. 1957. Sotaa ja rauhaa rautaesiripun molemmin puolin. Hämeenlinna: Nide.

Ariès, Philippe. (1960) 1975. L'enfant et la vie familiale sous l'ancien régime. Paris: Seuil. 
Assmann, Jan. 1995. "Collective Memory and Cultural Identity." New German Critique 65: 125-133. https://doi.org/10.2307/488538.

Augustinus, Aurelius. (397-400) 1981. Confessiones. Turnhout: Brepols.

Bond, Lucy ja Jessica Rapson. 2014. The Transcultural Turn: Interrogating Memory between and beyond Borders. Berlin: De Gruyter. https://doi.org/10.1515/9783110337617.

Buckley, Jerome Hamilton. 1974. Season of Youth: The Bildungsroman from Dickens to Golding. Cambridge, Massachusetts: Harvard University Press. https://doi.org/10.4159/ harvard.9780674732728.

Burt, Raymond. L. 2001. "The Bildungsroman." Teoksessa Encyclopedia of Life Writing. Autobiographical and Biographical Forms, toimittanut Margaret Jolly, 105-107. London: Fitzroy Dearborn.

Coe, Richard N. 1984. When the Grass Was Taller: Autobiography and the Experience of Childhood. New Haven: Yale University Press.

Coveney, Peter. (1957) 1967. The Image of Childhood: The Individual and Society: A Study of the Theme in English Literature. Harmondsworth: Penguin.

Davydova, Olga. 2009. Suomalaisena, venäläisenä ja kolmantena. Etnisyysdiskursseja transnationaalissa tilassa. Joensuu: Joensuun yliopisto.

De Cesari, Chiara ja Ann Rigney. 2014. Transnational Memory: Circulation, Articulation, Scales. Berlin: De Gruyter. https://doi.org/10.1515/9783110359107.

Douglas, Kate. 2010. Contesting Childhood: Autobiography, Trauma, and Memory. New Brunswick, New Jersey ja London: Rutgers University Press.

Eakin, John Paul. 1992. Touching the World: Reference in Autobiography. Princeton: Princeton University Press. https://doi.org/10.1515/9781400820641.

Ekberg, Henrik. 1991. Führerns trogna följeslagare. Den finländska nazismen 1932-1944. Tammisaari: Schildts.

Ekholm, Kai. 2000. Kielletyt kirjat 1944-1946: Yleisten kirjastojen kirjapoistot vuosina 19441946. Jyväskylä: Things to come.

Erll, Astrid. 2011 a. Memory in Culture. Basignstoke, Houndmills: Palgrave Macmillan. https:// doi.org/10.1057/9780230321670.

Erll, Astrid. 2011b. "Travelling Memory." Parallax 17(4): 4-18. https://doi.org/10.1080/13534 645.2011.605570.

Erll, Astrid. 2017. "Media and the Dynamics of Memory: From Cultural Paradigms to Transcultural Premediation." Teoksessa Handbook of Culture and Memory, toimittanut Brady Wagoner. New York, NY: Oxford University Press. https:doi.org/10.1093/ oso/9780190230814.001.0001.

Erll, Astrid. 2018. "Homer: A Relational Mnemohistory." Memory Studies 11(3): 274-286. https://doi.org/10.1177/1750698018771858.

Erll, Astrid ja Ann Rigney. 2009. "Introduction: Cultural Memory and its Dynamics."Teoksessa Mediation, Remediation, and the Dynamics of Cultural Memory, toimittaneet Astrid Erll ja Ann Rigney, 1-11. Berlin: De Gruyter.

Flink, Toivo. 2000. Maaorjuuden ja vallankumouksen puristuksessa: Inkerin ja Pietarin suomalaisten sivistys-, kulttuuri-ja itsetuntopyrkimyksiä vuosina 1861-1917. Turku: Turun yliopisto. 
Flink, Toivo. 2010. Kotiin karkotettavaksi: Inkeriläisen siirtoväen palautukset Suomesta Neuvostoliittoon vuosina 1944-55. Helsinki: Suomalaisen Kirjallisuuden Seura.

Genette, Gérard. 1997. Paratexts. Thresholds of Interpretation. Cambridge: Cambridge University Press. https://doi.org/10.1017/CBO9780511549373.

Gullestad, Marianne. 1996. "Modernity, Self, and Childhood in the Analysis of Life Stories." Teoksessa Imagined Childhoods. Self and Society in Autobiographical Accounts, toimittanut Marianne Gullestad, 1-39. Oslo: Scandinavian University Press.

Hakamies, Pekka. 1991. "Inkeri monietnisenä alueena." Teoksessa Inkeri: Historia, kansa, kulttuuri, toimittaneet Pekka Nevalainen ja Pekka Hakamies, 197-204. Helsinki: Suomalaisen Kirjallisuuden Seura.

Heimo, Anne. 2017."The Italian Hall Tragedy 1913: A hundred years of remediated memories." Teoksessa The Twentieth Century in European Memory: Transcultural mediation and reception, toimittaneet Tea Sindbæk Andersen ja Barbara Törnquist-Plewa, 240-267. Bedfordshire: Brill.

Huttunen, Laura. 2002. Kotona, maanpaossa, matkalla: Kodin merkitykset maahanmuuttajien omaelämäkerroissa. Helsinki: Suomalaisen Kirjallisuuden Seura.

Huyssen, Andreas. 2003. Present Pasts: Urban Palimpsests and the Politics of Memory. Stanford, California: Stanford University Press.

Hynninen, Anna. 2017. Minä, lotta, vaimo, äiti: Kerronnan variaatio ja toimijuus aktiivikertojan muistelukerronnassa. Turku: Turun yliopisto

Hytönen, Kirsi-Maria. 2014. "Ei elämääni lomia mahtunut": Naisten muistelukerrontaa palkkatyöstä talvi- ja jatkosotien ja jälleenrakennuksen aikana. Joensuu: Suomen Kansantietouden Tutkijain Seura.

Immonen, Kari. 1987. Ryssästä saa puhua... Neuvostoliitto suomalaisessa julkisuudessa ja kirjat julkisuuden muotona 1918-1939. Helsinki: Otava.

Isomaa, Saija.2009. Heräämisten poetiikkaa:LajejajaintertekstejäArvidJärnefeltin romaaneissa Isänmaa, Maaemon lapsia ja Veneh'ojalaiset. Helsinki: Suomalaisen Kirjallisuuden Seura.

Jänis, Marja. 2007. "Juhani Konkka (1904-1970)."Teoksessa Suomennoskirjallisuuden historia 2, toimittaneet H. K. Riikonen, Urpo Kovala, Pekka Kujamäki ja Outi Paloposki, 473-476. Helsinki: Suomalaisen Kirjallisuuden Seura.

Jääskeläinen, Anni. 2001. Karkotetut: Stalinin ajan karkotuksien merkitykset ja myyttinen historia inkerinsuomalaisen suvun kertomana. Pro gradu -tutkielma. Helsinki: Helsingin yliopisto.

Kaivola-Bregenhøj, Annikki. 1998. “Life as Narrative: Ingrian Finns Tell about their Vicissitudes." Teoksessa Ingrians and Neighbours: Focus on the Eastern Baltic Sea Region, toimittaneet Markku Teinonen ja Timo J. Virtanen, 48-60. Helsinki: Finnish Literature Society.

Kaljundi, Linda, Eneken Laanes ja Ilona Pikkanen. 2015. Novels, Nations, Novel Nations: Historical Fiction and Cultural Memory in Finland and Estonia. Helsinki: Finnish Literature Society. https://doi.org/10.21435/sfh.19.

Kallio, Kati. 2013. Laulamisen tapoja. Esitysareena, rekisterija paikallinen laji länsi-inkeriläisessä kalevalamittaisessa runossa. Helsinki: Helsingin yliopisto.

Koivisto, Päivi. 2005."Minähän se olen! Miten elämästä tulee fiktiota Pirkko Saision romaanissa Pienin yhteinen jaettava." Teoksessa Lajit yli rajojen: Suomalaisen kirjallisuuden lajeja, toimittaneet Lyytikäinen, Pirjo, Jyrki Nummi ja Päivi Koivisto, 177-205. Tietolipas 207. Helsinki: Suomalaisen Kirjallisuuden Seura. 
Konkka, Anita. 1985. Samaa sukua: Romaani. Helsinki:Tammi.

Konkka, Anita. 1995. Johanneksen tunnustukset. Helsinki: Tammi.

Konkka, Anita. 2001. Musta passi. Helsinki: Tammi.

Konkka, Juhani. 1943. Kulkurin kesä: Romaani. Porvoo: Werner Söderström Osakeyhtiö.

Konkka, Juhani. 1945. Kulkurin kahleet: Romaani. Porvoo: Werner Söderström Osakeyhtiö.

Konkka, Juhani. 1946. Kulkurin koulut: Romaani. Porvoo: Werner Söderström Osakeyhtiö.

Konkka, Juhani. 1947. Tuhlattu aarre, eli, Sakari Korkian seikkailut Helsingin kirjailija- ja boheemimaailmassa. Porvoo: Werner Söderström Osakeyhtiö.

Koskela, Lasse. 1997. "Konkka, Juhani." Kansallisbiografia-verkkojulkaisu. Studia Biographica 4. Helsinki: Suomalaisen Kirjallisuuden Seura. https://kansallisbiografia.fi/ kansallisbiografia/henkilo/4975.

Kosonen, Päivi. 2000. Elämät sanoissa: Eletty ja kerrottu epäjatkuvuus Sarrauten, Durasin, Robbe-Grillet'n ja Perecin omaelämäkerrallisissa teksteissä. Helsinki: Tutkijaliitto.

Kuhn, Reinhard. 1982. Corruption in Paradise: The Child in Western Literature. Hannover: University Press of New England.

Kuismin, Anna. 2010. "Hänen itsensä kertomana: 1800-luvun kansanihmiset ja oman elämän kirjoitus." Teoksessa Lukeva ja kirjoittava työläinen, toimittaneet Kirsti Salmi-Niklander, Sami Suodenjoki ja Taina Uusitalo, 21-47. Helsinki: Työväen historian ja perinteen tutkimuksen seura.

Kuortti, Aatami. 1934. Pappina, pakkotyössä, pakolaisena: Inkeriläisen papin kokemuksia Neuvosto-Venäjällä. Porvoo: Werner Söderström Osakeyhtiö.

Kurki, Tuulikki. 2018. Rajan kirjailijat: Venäjän Karjalan suomenkieliset kirjailijat tilan ja identiteetin kirjoittajina. Helsinki: Suomalaisen Kirjallisuuden Seura.

Kõresaar, Ene, Kristin Kuutma ja Epp Lauk. 2009. "The Twentieth Century as a Realm of Memory." Teoksessa The Burden of Remembering: Recollections \& Representations of the 20th Century, toimittaneet Kõresaar, Ene, Kristin Kuutma ja Epp Lauk, 9-34. Helsinki: Finnish Literature Society.

Lassila, Pertti. 2002. Keisarin kankurit ja muita kirjoituksia kirjoista ja kirjailijoista. Helsinki: Yliopistopaino.

Lejeune, Philippe. 1989. On Autobiography. Minneapolis: University of Minnesota Press.

Levy, Daniel ja Natan Sznaider. 2002. "Memory Unbound: The Holocaust and the Formation of Cosmopolitan Memory." European Journal of Social Theory 5(1): 87-106. https://doi. org/10.1177/1368431002005001002.

Linna, Matti. 2014. Kirjailija ja kansallinen sosialisti: Juhani Konkka poliittisena toimijana Yrjö Ruudunaatteidenpohjallesyntyneissäkäytännönhankkeissavuosina 1927-1934.Progradu -tutkielma. Tampere: Tampereen yliopisto. http://urn.fi/URN:NBN:fi:uta-201412112422.

Luostarinen, Heikki. 1986. Perivihollinen: Suomen oikeistolehdistön Neuvostoliittoa koskeva viholliskuva sodassa 1941-1944: tausta ja sisältö. Tampere: Vastapaino.

Löschnigg, Martin. 2005. "Autobiography." Teoksessa Routledge Encyclopedia of Narrative Theory, toimittaneet David Herman, Manfred Jahn ja Marie-Laure Ryan. London \& New York: Routledge.

Matley, Ian M. 1979. "The Dispersal of the Ingrian Finns." Slavic Review 38(1): 1-18. https:// doi.org/10.2307/2497223. 
Miettinen, Helena. 2004. Menetetyt kodit, elämät, unelmat: Suomalaisuus paluumuuttajastatukseen oikeutettujen venäjänsuomalaisten narratiivisessa itsemäärittelyssä. Helsinki: Helsingin yliopisto.

Moretti, Franco 1987. The Way of the World: The Bildungsroman in European Culture. London: Verso.

Nevalainen, Pekka. 1990. Inkeriläinen siirtoväki Suomessa 1940-luvulla. Helsinki: Otava.

Nevalainen, Pekka. 1991. "Inkerinmaan ja inkeriläisten vaiheet 1900-luvulla." Teoksessa Inkeri: Historia, kansa, kulttuuri, toimittaneet Pekka Nevalainen ja Pekka Hakamies, 234299. Helsinki: Suomalaisen Kirjallisuuden Seura.

Nevalainen, Pekka. 1999. Viskoi kuin luoja kerjäläistä: Venäjän pakolaiset Suomessa 19171939. Helsinki: Suomalaisen Kirjallisuuden Seura.

Nevalainen, Pekka. 2006. Karjalan kansaa valistamassa: Itä-Karjalan pakolaiset opinteillä Suomessa. Helsinki: Suomalaisen Kirjallisuuden Seura.

Ojala, Ella. 1988. Pitkä kotimatka. Helsinki: Tammi.

Ojala, Ella. 1990. Suomi näkyy. Helsinki: Tammi.

Ojala, Ella. 1994. Ensimmäinen kevät. Helsinki:Tammi.

Paloposki, Outi. 2009. "Limits of Freedom: Agency, Choice and Constraints in the Work of the Translator."Teoksessa Agents of Translation, toimittaneet John Milton ja Paul Bandia, 189-208. Amsterdam: John Benjamins.

Pattison, Robert. 1978. The Child Figure in English Literature. Athens: The University of Georgia Press.

Peltonen, Ulla-Maija. 2009. "Memories and Silences: On the Narrative of an Ingrian Gulag Survivor." Teoksessa Memories of Mass Repression: Narrating Life Stories in the Aftermath of Atrocity, toimittaneet Nanci Adler, Selma Leydesdorff, Mary Chamberlain ja Leyla Neyzi, 61-79. New Brunswick, New Jersey: Transaction Publishers.

Rantanen, Vilho. 1935. Ristin ja Siperian tie: Kappale kahden Siperiaan karkoitetun ja Siperiasta paenneen inkeriläisen kohtalon tiestä. Jyväskylä: Gummerus.

Reijonen, Merja. 2002. Tila ja kulttuurinen identiteetti: Entisen Neuvostoliiton alueelta tulleiden paluumuuttajien kulttuurisen identiteetin muodostuminen Suomessa asutun vuoden aikana. Helsinki: Helsingin yliopisto.

Rigney, Ann. 2005. "Plenitude, Scarcity and the Circulation of Cultural Memory." Journal of European Studies 35(1): 11-28. https://doi.org/10.1177/0047244105051158.

Rigney, Ann. 2016. "Cultural Memory Studies: Mediation, Narrative, and the Aesthetic." Teoksessa Routledge Handbook of Memory Studies, toimittaneet Anna Lisa Tota ja Trever Hagen, 66-76. London \& New York: Routledge, Taylor \& Francis Group.

Ronkonen, Lyyli. 1989. Laps' Inkerin: Muistojen Inkeri Stalinin hirmuvallan alla. Jyväskylä: Gummerus

Ronkonen, Lyyli. 1990. Inkeri - isänmaa kallis. Jyväskylä: Gummerus.

Rousseau, Jean-Jacques. (1782) 1891. Les Confessions. Paris: Garnier.

Rousseau, Jean-Jacques. (1762) 1904. Émile ou de l'éducation. Paris: Garnier.

Salonsaari, Minna-Liisa. 2018. Inkerinsuomalaisten paluumuutto kerrottuna paluumuuttona ja kulttuuriperintöprosessina. Turku: Turun yliopisto.

Sanders, Valerie. 2001. "Childhood and Life Writing." Teoksessa Encyclopedia of Life Writing, toimittanut Margaret Jolly, 203-204. London: Fitzroy Dearborn. 
Savolainen, Ulla. 2015. Muisteltu ja kirjoitettu evakkomatka: Tutkimus evakkolapsuuden muistelukerronnan poetiikasta. Joensuu: Suomen Kansantietouden Tutkijain Seura.

Savolainen, Ulla. 2016. "The Genre of Reminiscence Writings: Applying the Bakhtin Circle's Genre Theories." Teoksessa Genre - Text - Interpretation: Multidisciplinary Perspectives on Folklore and Beyond, toimittaneet Frog, Kaarina Koski ja Ulla Savolainen, 203-231. Helsinki: Finnish Literature Society.

Savolainen, Ulla. 2017a. "The Return: Intertextuality of the Reminiscing of Karelian Evacuees in Finland." Journal of American Folklore 130(516): 166-192. https://doi.org/10.5406/ jamerfolk.130.516.0166.

Savolainen, Ulla. 2017b . "Tellability, frame and silence: The emergence of internment memory." Narrative Inquiry 27(1): 24-46. https://doi.org/10.1075/ni.27.1.02sav.

Savolainen, Ulla. 2018. "Points and Poetics of Memory: (Retrospective) Justice in Oral History Interviews of Former Internees." Memory Studies. Julkaistu ensin verkossa 22.10.2018. https:// doi.org/10.1177/1750698018806946.

Scudder, Horace. 1894. Childhood in Literature and Art: With Some Observations on Literature for Children. Boston \& New York: Houghton, Mifflin \& Co.

Sihvo, Hannes. 1991. "Inkerinmaata ja inkeriläisiä kirjallisuudessa." Teoksessa Inkeri: Historia, kansa, kulttuuri, toimittaneet Pekka Nevalainen ja Pekka Hakamies, 319-342. Helsinki: Suomalaisen Kirjallisuuden Seura.

Smith, Sidonie ja Julia Watson. 2001. Reading Autobiography: A Guide for Interpreting Life Narratives. Minneapolis: University of Minnesota Press.

Survo, Arno. 2001. Magian kieli:Neuvosto-Inkerisymbolisenaperiferiana. Helsinki:Suomalaisen Kirjallisuuden Seura.

Tarmio, Janne. 1985. Kirjailijoiden YKK: Yhteiskunnallinen Korkeakoulu kirjallisuudessa ja kirjailijat Yhteiskunnallisessa Korkeakoulussa. Tampere: Tampereen yliopisto.

Taavetti, Riikka. 2018. Queer Politics of Memory: Undisciplined Sexualities as Glimpses and Fragments in Finnish and Estonian Pasts. Helsinki: University of Helsinki.

Torikka, Urho. 1929. Me sankarit: Kuvaus Karjalan retkeltä. Helsinki: Kansanvalta.

Torikka, Urho. 1931. Punainen myrsky: Romaani Inkerinmaalta. Helsinki: Otava

Vertovec, Steven. 2009. Transnationalism. London: Routledge. https://doi. org/10.4324/9780203927083.

Vettenniemi, Erkki. 2001. Surviving the Soviet Meat Grinder: The Politics of Finnish Gulag Memoirs. Helsinki: Aleksanteri Institute.

Zipfel. Frank 2005. "Autofiction." Teoksessa Routledge Encyclopedia of Narrative Theory, toimittaneet David Herman, Manfred Jahn ja Marie-Laure Ryan. London \& New York: Routledge.

FT Ulla Savolainen työskentelee Suomen Akatemian tutkijatohtorina Helsingin yliopistossa folkloristiikan oppiaineessa. Memory Unchained -hankkeessaan hän tutkii inkeriläisten kokemuksia käsittelevää kirjallisuutta kulttuurisen muistin näkökulmasta. 